\title{
A KITE FOR SARAH
}

\section{In search of freedom.}

\section{BY DAVID G. BLAKE}

"W hat's it like when they shut one down, Papa?"

Sarah watched me, her emerald eyes cut with a purity I refused to blemish. I lied to her instead. "I don't know, sweetie."

"I bet it's a lot like being a kite that's lost and floating high in the sky."

The truth veered more towards being the one punished for losing the kite, yet I spared her again. "That sounds wonderful."

"I'll ask Mother. She knows everything."

Nothing could be further from what I wanted. Her mother would grind that beautiful innocence into a nub of ugly truth. I calmed myself by imagining I really was like a lost kite soaring high. It felt so ... so free.

"You know she'll be tired when she gets home from work. Put on your pyjamas, brush your teeth and go to bed. We can talk tomorrow."

Her bottom lip jutted in an exaggerated pout and she stomped away; but it was not in her nature to stay mad for long. She poked her head out from the bathroom a few moments later. "I love you, Papa," she said, her smile an aureole of smeared toothpaste and happiness.

"I love you, sweetheart." A truth that magnified my suffering a hundredfold and made it somehow bearable at the same time.

\section{Elizabeth stormed in around eleven.}

I blocked the stairs and mustered what I hoped would not prove to be the last scrap of defiance left in me. "They shut her teacher off today. Right in front of the class."

Her green eyes - so much like Sarah's, yet so different - thinned. She tugged off her gloves one finger after another and tossed them onto the counter top. "She questioned you?"

My answering nod felt heavy, laden with betrayal.

"And how did you respond?"

"I lied."

She slapped me. Softly. Hard would have shown a measure of respect instead of cold indignation. "Don't be impertinent."

"I told her I didn't know."

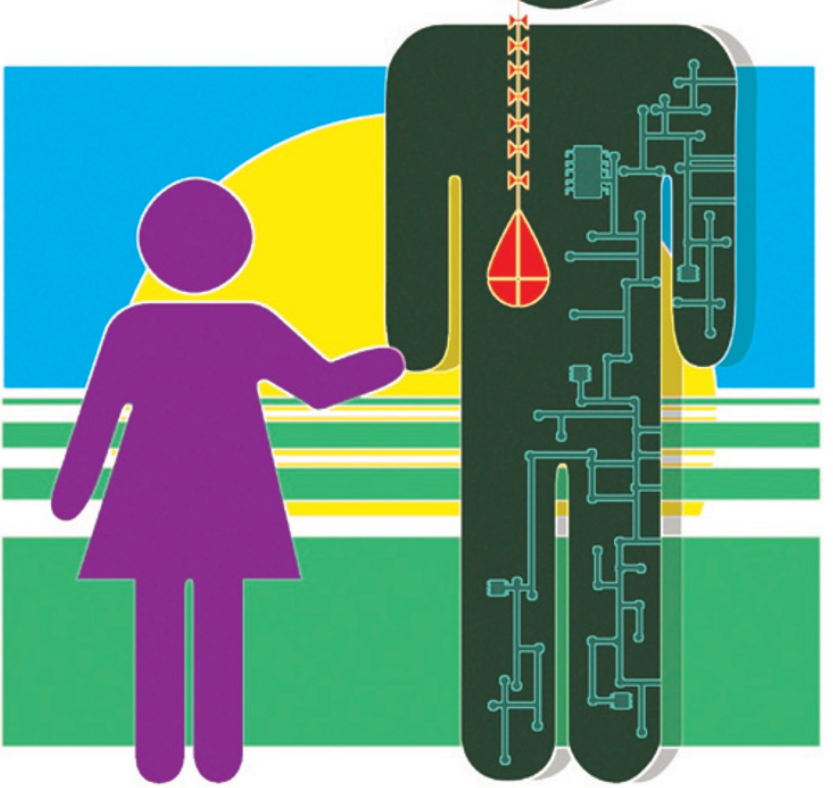

unrepressed enthusiasm. I marvelled at how such a thing could make her $\stackrel{0}{7}$ so utterly happy.

We walked to the field behind our house, and I showed her how to make the kite fly. She ran back and forth, gaze fixed on the whirling red teardrop. I joined her, arms spread wide as if I might also catch an updraft and soar away; it was a nice thought while it lasted. She laughed and spread her arms like mine, eyes reflecting the life of the summer grass. The kite circled above us with purpose, tethered only for so long as Sarah's grip remained true; in such we were more alike than I had imagined.

The sun scampered across the sky towards the frowning horizon. I stopped running in circles and twirled her around instead, losing myself in her laughter a little while longer. Just like that, our last day together started to end. "We should head back," I said. "Your mother's
"That'll have to do, I suppose. I'll make the necessary arrangements in the morning."

"Please, Elizabeth, I don't think she is ready."

"Are you sure it is Sarah who is not ready?" She held up her hand. "Don't bother giving an answer. It's not your place to think. You're to do as encoded until your usefulness has run its course. You remember what happens after that, don't you?"

"But sh -"

"You'll never replace Peter. Never. I don't care how much you look like him. Now get out of my sight. Your face disgusts me."

I snuck upstairs and watched Sarah sleep. Several times throughout the night, I almost woke her and confessed everything, but I could not so easily relinquish what little time we had left together. I also loathed the idea of my little girl becoming like her mother, and the quicker she learned the truth, the sooner that would be.

"Are we truly going to fly a kite, Papa?"

I nodded, afraid my voice would break to match my heart if I tried to speak; I had planned the day knowing it would be our last spent together.

She clutched the kite - just a simple red one shaped like a teardrop - with $\rightarrow$ NATURE.COM Follow Futures: @ @ NatureFutures f go.nature.com/mtoodm going to be home soon." I knew Elizabeth would not be late, not on this night.

"Do we have to, Papa?"

"I'm afraid so, honey." Such a truth made nothing bearable. "Want me to show you how to spool the kite?"

"No. I want to let it go free."

Free. What a powerful word. To hear it uttered by her, even once, was more than I could have hoped. I had decided - while I planned our last day, or perhaps later when I spun her in my arms and lost myself in her laughter - to tell her the truth; risk even more suffering, so that she would understand. But this was how I wanted her to remember me.

"Go ahead." It was nice to know I still had a crumb of defiance left in me. "Set it free."

Her hands opened like a summertime bloom. The kite rode the wind into the darkening sky, our similarities ending in one last flicker of red. "Will it go to heaven, Papa?"

I brushed away my tears before she could spot them. "I am sure it will float somewhere nice, sweetheart."

David G. Blake lives in Pennsylvania with his girlfriend and their chocolate Labrador. In addition to Nature, his work has appeared in Beneath Ceaseless Skies, Daily Science Fiction and several other publications. For more info, visit his Facebook page. 